HSS V.3 (2016)

DOI: $10.1515 /$ hssr -2016-0024

\title{
Textual Anastomosis: About the Vanishing Body and the Resurrection of a Character. A Transversal Reading of Black Water (1992) and Mudwoman (2012) by Joyce Carol Oates
}

Andreea Pop*

Babeş-Bolyai University, Cluj-Napoca, Romania

\begin{abstract}
In 1992, the much acclaimed prolific American writer Joyce Carol Oates publishes Black Water - a very harsh and condensed literary reenactment of a gruesome event having taken place more than twenty years before and known as the "Chappaquiddick incident". Another twenty years later, through her 2012 novel Mudwoman, the author seems to revisit the topic that had haunted her for decades. This paper aims at establishing a certain narrative pattern connecting the two novels not only thematically, but also phantasmatically: the sudden "resurrection" of Joyce Carol Oates's character in the 2012 novel is, as we see it, far from being "incidental". By "textual anastomosis", we understand a subjective association of narratives in order to show how the disembodied consciousness "travels" from one character's fictional body to another's, triggering a whole bunch of personal memories which also resurrect in this other character's fictional biography.
\end{abstract}

Keywords

Consciousness, Death, Disembodiment, Narrative, Regression, Selfhood, Vanishing body

\footnotetext{
Babeş-Bolyai University Cluj-Napoca, Faculty of Letters, str. Horea nr. 31, Cluj-Napoca, 400202; email: pop_a80@yahoo.com
} 
In 1969, Mary Jo Kopechne, a staff member of the 1968 campaign for Senator Edward (Ted) Kennedy attends a party on Chappaquiddick Island, next to Martha's Vineyard, Massachusetts. Leaving in company of the Senator, the young woman loses her life after the car driven by Kennedy flies off the road into the muddy waters of a channel. The Senator is given a two month suspended prison sentence for not having reported the incident for several precious hours which could have led to the young female being rescued ${ }^{1}$ - a court decision that scandalized America and shattered his political chances to Presidency. Joyce Carol Oates 1992 novel fictionalizes this real life event: Mary Jo Kopechne becomes Elisabeth Anne Kelleher, (Kelly, or Lizabeth/Lizzie, as a young child), whilst Ted Kennedy is only referred to as "the Senator", driving a rented Toyota along a bumpy unpaved road surrounded by marshland in the fictional Grayling Island, Maine. The author's attempt to make the victim's voice heard ${ }^{2}$ originates in the tragic silence surrounding Mary Jo Kopechne's death and in the actual need to get her side of the story. Soon though, the reader understands that the novel exceeds its purpose: Black $W$ ater is a book about the survival of the disembodied consciousness and the preservation of the self. Kelly is sinking deeper and deeper into the muddy water and this experience instantly breaks the unity of her whole world into parallel universes made of glimpses of the past and personal projections about an improbable future. Kelly "travels" through various stages of her personal history stretching from the moment of the slid, when, "with no warning, somehow the car has gone off the road and had overturned in black rushing water"3 (Oates, 1994: 3, chapter 1) to the very last drop of life, when, in asphyxia, the young woman projects herself as a small girl - a "defiant child" swimming in a suddenly clear water to her salvation (Oates, 1994: 153, chapter 32, the last one).

Twenty years after the release of Black $W$ ater, Joyce Carol Oates publishes Mudwoman, in which she revisits the same theme and motifs explored in the 1992 novel (suffocation in mud, death, reconfiguration of the self, birth of a new consciousness). The novel tells the story of a successful female University President Meredith Ruth (M. R.) Neukirchen, the adoptive daughter of a Quaker family who returns to Black Snake River, in the region of Adirondacks, New York - the origin 
of her inner journey ${ }^{4}$.

Without being openly connected, the two novels seem to share more than a thematic background. In more than one respect Mudwoman could be read as a sequel to Black Water: the death of Kelly Kelleher is thus followed by a late resurrection, exactly twenty years later, as M. R., through what we argue to be a "textual anastomosis", unfolding as a three-step process.

\section{1. (Re)fictionalizing Fiction. Drawing Closer the Edges}

The novels seem to be connected through a network of invisible threads underlying the respective narratives: in her last seconds of life, the dying woman enters a state of regression to the age of early childhood. She is thus granted a symbolic resurrection as Jewel Kraeck at nearly the same age Kelly was in her projection:

She was swallowing the black water in quick small mouthfuls, reasoning that if she swallowed enough she would be simply drinking it, she would be all right.

What is that - for her? - staring in blinking astonishment and elation at what Grandma had sewed her, a dress in white pucker-cotton printed with tiny strawberries, she would wear it with the black patent-leather shoes and the white anklet socks trimmed in pink (Oates, 1994: 151).

In her own projection, Kelly becomes a variation of Lewis Carroll's Alice in Wonderland, in a pretty dress, with white socks and shoes, somehow falling into a rabbit-hole/well and entering another temporal dimension $^{5}$. Unlike Alice though, whose free fall in the well is unstoppable, Kelly finds her way out through disembodiment, upwards, in the "elation" of a spiritual nature.

And still, leaving the fictional body creates the need to find another one. The 2012 story comes from such a necessity: one fiction yields the other, as Kelly's restless fictional ethereal being of a three year old reintegrates another three year old fictional body: Jewel's. Alice's rabbithole is thus the twenty years gap of extrafictional time and space between the two narratives. Resurrected as young Jewel, she is rescued from the black water in a deplorable state. This symbolic embodiment is 
HSS, vol. V, no. 3 (2016): 77-92

nevertheless a very difficult process: Jewel's body is abused, beaten and cut, in rags. The ethereal Alice-like bodily engram of the three year old Kelly Kelleher thus integrates a sacrificial flesh-and-bone body, precarious, but alive:

The part-conscious child tries to open her eyes. The right eye is swollen shut but the left eye opens - just barely - there's flutter of eyelashes - and the little fish-mouth is pursed to breathe, to breathe, and to whimper as if weakening to life [...] she is near-naked, in what appears to be the remnants of a torn paper nightgown all mated with mud, slick and glistering with mud and there is mud caked on the child's shaved head amid sores, scabs, bruises, and so little evidence of hair, no one could have said what color the child's hair is (Oates, 2012: 66).

While Kelly was forced to drink the muddy water as if she'd tried to break the chemical bond and extract the oxygen from it, young Jewel is now gasping for air, as if arrived from underneath after having crossed the well of time and found the surface. A sort of intricate network of invisible threads bind Black Water and Mudwoman into a rhizomatic structure as Gilles Deleuze and Félix Guattari intend it. These "lines of flight" linking the two novels "always tie back to one another. That is why one can never posit a dualism or a dichotomy, even in the rudimentary form of the good and the bad" (Deleuze \& Guattari, 2005: 9).The very completeness of such a stable configuration is validated by several thematic horizontals, for in the two novels a series of recurrent motifs interconnect just like capillaries. We retain:

a) the doll: in both Black Water and Mudwoman, the image of a doll precedes the contact with water and trigger projective mechanisms and

b) garbage: in both novels, the human body integrates a chain of equivalence with dumped, disposable goods.

The last image Kelly sees before the Senator's rented Toyota goes off the road into the black water is a damaged doll, left astray amongst garbage:

[...] Kelly saw without registering she saw (for she and the Senator were 
HSS, vol. V, no. 3 (2016): 77-92

talking) in a shallow ditch beside the road a broken dinette table, the front wheel of an English racing bicycle, the headless naked body of a flesh-pink doll... Looking away from the doll. Not wanting to see the whole between the shoulders like a bizarre mutilated vagina where the head had been wrenched off (Oates, 1994: 149).

Figuring the impossible escape (the wheel) from a dead-end situation which reifies women into the very symbol of their femininity (the space "between the shoulders" as a "vagina") the body thus integrates a system of equivalences stretching from inutility to abuse. Before Kelly Kelleher's eyes stands a rather accurate description of her situation and of the instrumental role she's playing in the world of this powerful man who's driving her to her death. Reification and projection are therefore at the heart of the fictionalized reality of Black Water: the woman's body is but a vessel for male desire. Completely defenseless before the US Senator, Kelly-Mary Jo is nothing but a broken doll with a vagina-like hole instead of a head.

In Mudwoman too, the marshland scenery is filled with garbage, of "broken things", "a man's right boot", "a shredded tractor tire", "strips of plastic". In this end-of the-world image of loss and decay, "tracks ran in all directions, with a look of frenzied determination." (Oates 2012: 61). Symbol of man's power, the deserted boot is a constant reminder of the male hegemony, whilst the tracks function as both remnants of presence and "lines of flight", as Deleuze and Guattari understand them, which seem to connect the two fictions from a thematic point of view. In this very image of desolation, Meredith Ruth's rescuer sees

[a] child's rubber doll, badly battered, hairless, unclothed, and its coloring mostly flaked off - too light to sink in the mud and so it was floating on the surface in the way to cause Suttis's heart to trip even as he told himself Damn thing's only a doll (Oates, 2012: 62).

The "battered" "hairless" Jewel/ Meredith Ruth's rescuer first sees is strikingly similar to the little girl herself, the very image of violence and abuse, with swollen eyes, scalp injuries, and dressed in rags. The triadic representation of dismay and destruction develops from garbage to doll and doll-identification as a broken image of the self which gradually 
animates into a living child reconstruct another triadic structure in Black $W$ ater, relying on the same motifs (doll, garbage) as predictions of what is about to unleash. The vanishing consciousness of Kelly Kelleher is balanced by a gradually reconstructed "bodiness" in Mudwoman: Kelly comes to surface not as the girl she once was but as a reversed representation of an Alice, having undergone some major transformation during the passage from one fiction to the other.

Trapped in her own body and in a metal cage that wouldn't let her go, Kelly's last Alice in Wonderland image of herself at the happiest age functions as a "channel" or a "well" connecting her to a new existence as Jewel/ Meredith Ruth Neukirchen, after having been rescued from the same mud that had taken Kelly's life. She is thus granted a new beginning that relaunches the question of the status of fiction and how fiction works relate to each other as well as to the extrafictional reality (here, the Chappaquiddick accident): reality creates a reality-like variation of itself (Black Water), later refictionalized in Mudwoman.

\section{Reconfiguring Fictional Facts. Stitching the Edges}

The two novels share several features related to the use of some identical elements which tend to construct a common ground for the fictional existences. Nevertheless, seen in each individual fictional context, they underline significant differences. A number of such elements "travel" from Black Water to Mudwoman and give birth to new and unexpected nuances.

\subsection{The "Rented Toyota"}

In Black Water, Kelly is more than happy to be leaving the $4^{\text {th }}$ of July party on the Grayling Island in the company of the Senator, in his rented car:

The rented Toyota, driven with such impatient exuberance by The Senator, was speeding along the unpaved unnamed road, taking the turns in giddy skidding slides, and then, with no warning, somehow the car had gone off the road and had overturned in black rushing water, listing to its passenger's side, rapidly sinking.

Am I going to die? Like this? (Oates, 1994: 3) 
The Senator's aggressive driving of an equally aggressive car underlines his maleness. The car thus becomes an exterior symbol of empowerment, which also hints at his political influence. The woman inside it is therefore trapped in an intricate network of unseen dangerous connections and unforeseen consequences, a barely innocent witness of such an evident display of wealth and sufficiency.

In Mudwoman, Meredith Ruth revisits her past on the occasion of a conference held in the proximity of the marshland region from which she had been rescued in early childhood. She therefore rents a Toyota herself, in order to be free to stroll amid the places of memory. In opposition to Kelly, who is the passive passenger and whose life is being determined by the Senator who is the very incarnation of power, Meredith Ruth masters the wheel "like a man" (Oates, 2012: 34). The fact that she's renting the same type of car when coming back to face the inner reality of a traumatic past could be read as a distant echo of a personal history that has apparently nothing to do with the present:

[...] she was driving in odd rushing and jolts pressing her foot on the gas pedal and releasing it - she was hoping not to be surprised by whatever lay ahead and yet, she was surprised - shocked:" Oh God!"

For there was a child lying at the side of the road -a small figure lying at the side of the road broken, discarded. The Toyota veered, plunged off the road into a ditch. [...]

So quickly it had happened! M. R.'s heart lurched in the chest. She fumbled to open the door, and to extract herself from the seat belt. The car engine was still on - a violent peeping has begun. She'd thought it had been a child at the roadside but of course - she saw now - it was a doll (Oates, 2012: 45).

The symbolic reembodiment of Kelly Kelleher's fictional ethereal "spirit" into Meredith Ruth's flesh-and-bone body triggers memories which are and are not exactly hers. The incident shakes up profoundly the heroine of Mudwoman: a doll, as in Kelly's last recollection before the accident, surges in Meredith Ruth's consciousness with the force of an instant recognition. The journey from one (fictional) life to the other is the adventure of the disembodied fictional consciousness in search of a 
HSS, vol. V, no. 3 (2016): 77-92

new fictional body. Meredith's own reaction to the incident states that glimpses of a transpersonal past have been transferred along with a whole memory "archive". Still, she is now in a far less vulnerable position: as the one who's driving, she is in control of her own destiny. But the universe has its means to restore an old reality and thus oppose some sort of resistance: the "doll" M. R. had mistaken for a child is in fact a bunch of child's clothing,

something white, cotton - underpants?- stiff with mud, stained. And socks, white cotton socks. And in the underbrush nearby the remains of a kitchen table with a simulated-maple Formica top. Rural America, filling up with trash. (Oates, 2012: 46).

The embodiment into this other, more resilient and more prepared body makes a very interesting turn: Kelly's projection about herself as a younger Alice leaves traces in the external fictional reality of Mudwoman: Meredith Ruth cannot relate to Kelly's disembodiment experience other than by taking it in, from inward, introjectively. Her visual delusion, which puts together different instant impressions (child- doll- bunch of clothes reminding Kelly's recollection/projection about herself at the age of three, in strawberries dress and white socks) mixes elements of an "objective", outer reality and glimpses of a past that is not her own. The vanishing body of the "young Alice" having deserted her clothes in the middle of the road installs a precarious blended reality bordered by the windshield of her rented car: outwards, there lays an objective world, material and present; inwards, it opens a subjective reality which triggers "flickers" of an embodied memory. The transfer of consciousness from one fictional character to the other asks for a continuous reconfiguration of the self, as Meredith Ruth, the mudwoman daughter of a madwoman, has to come to terms with this alien part of her biography. While driving, her inner monologue expresses a wisdom coming from Kelly's own experience, as if suggested by the drowned woman's own experience:

Death by (sheer) accident. Surely that was the most merciful of deaths.

Death at the hands of another: the cruelest.

Death by the hands of another who is known to you, close as a heartbeat. the very cruelest. (Oates, 2012: 45). 


\subsection{A Mirroring Identity}

The issue of the symbolic consciousness transfer from one character to the other also triggers difficulties of incorporation and identification. The self-recognition in the mirror leads to adjustment mechanisms as the inner self is trying to accommodate to the "new" fictional body it has come to inhabit.

A physical feature (an eye dissymmetry) seems to haunt Meredith Ruth's mind as being strangely alien to her, "[f]or often in mirrors Meredith saw, to her dismay, that one of her eyes was larger than the other one, or set at a different angle in her face" (Oates, 2012: 255). The self-reflection in the mirror makes Meredith Ruth think of her own "otherness": this eyes flaw is something she cannot relate to and thus she is unable to integrate in her body image. When reading Black Water closely, one comes to realize that Kelly had suffered from such a deformity in early childhood, surgically corrected when she was a very young child, since

[f]rom birth, Kelly had had an imbalance in her eye muscles, the name for the defect (you could not escape the fact, it was a defect), strabismus, meaning that, in Kelly's case, the muscles of the left were weaker than the muscles of the right (Oates, 1994: 21).

Still, after a simple surgical procedure, "recovery was swift, if not precisely painless as promised, and forever afterward the eye, the eyes, the girl, were, as all outer signs indicated, normal" (Oates, 2012: 24).

M. R.'s defect thus reminds of Kelly's before the corrective eye surgery indicates that the transfer of the disembodied consciousness into the three year old Mudgirl resides on Kelly's last projection as a young girl. It is thus this regressive state generated by the asphyxiated brain that defines the whole disembodiment process; it is in such a state that Kelly's consciousness integrates the other fictional body - Meredith Ruth's. Conscience thus forges an engram of the body it has just deserted which, once reincorporated, triggers significant physical changes in the other's fictional body. Mudwoman is therefore subjected to a kind of regression at the age of the reinforcement of the Self structures: she 
HSS, vol. V, no. 3 (2016): 77-92

decomposes the unity of the self into pieces that she feels alien to the configuration of her body image, isolating them from those she experiences as her own. She is taken back to the mirror stage as Jacques Lacan $^{6}$ understands it, a stage expressing

the symbolic matrix in which the $I$ is precipitated in a primordial form, prior to being objectified in the dialectic of identification with the other, and before language restores to it, in the universal, its function as subject (Lacan, 2006 [1949]: 76).

Meredith Ruth's regressive state is thus complicated by the estrangement to herself that originates in the nature of her multiple identities associated to the embodiment experience: when compared to Kelly's story, M.R.'s is placed in the logic of the dryness.

The heroine's fictional destiny oscillates between a troubled identity (as Jewel, Jedina, M. R. or M.) and an obscure but all too present alterity (as the fictionalized phantasmatic reincarnation of Kelly), which has to do with both mirrors and mirroring effects. In order to get to the truth of her existence, Kelly has to "shed" away multiple layers of a social self which thus resemble to the dried mud scraped off her little body the moment hed had been rescued from the marshland.

As a young girl, she had heard her adoptive father, Konrad Neukirchen, talk about the possibility of travelling through the ages of one's personal history and meeting a younger version of oneself as a symbolic twin in a confrontational fusion between past and present:

"For instance, Meredith: if you travel back to the time before you were born, you would discover a world in which you did not exist, but if you travel back to the time and discover a world in which after you'd been born, you would discover a world in which a younger twin self of your own existed! Only think." (Oates, 2012: 215)

Since early childhood Meredith has been prepared to admit the possibility of her alterity as a form to authenticate her very existence. Not only identity and alterity coexist, but one could attain the first by accepting the latter. Torn between her own issues and an otherness she cannot bring herself to ignore, Meredith Ruth's inner world is thus shaped as a broken mirror itself, made of glimpses of her own dramatic past and a problematic sense of belonging. 
HSS, vol. V, no. 3 (2016): 77-92

Selfhood is thus conditioned by an individual and a transindividual level of intra- and intertextual interest: shedding multiple layers of a social identity in Mudwoman relates to a "local" dislocation of the Self, whilst the same character is also "confronted" to a fiction-to fiction dilemmatic approach, as phantasmatic reincarnation of her twin self, Kelly Kelleher. Identity is thus restricted to Meredith's four or five "stages" of development of personality, from a young child to a teenager, then a young woman and finally an accomplished professional. Alterity, on the other hand, is a matter of embodiment of Kelly's fictionalized consciousness into Meredith Ruth's fictional body.

The issue of mirroring and of "mirror-imagery", as Richard Rorty calls it in Philosophy and the Mirror of Nature (Rorty 1979: 351) is nevertheless connected to the difficulties of integrating one's own "otherness" into the body schema as a propulsive force reverberating into one's own configuration of the world and of one's place in it. A stronger sense of the self emerges, as "this is the difference between the will to truth and the will to self-overcoming" (Rorty, 1989: 29), synonym of the personal growth, which, in Meredith Ruth's case, could be considered both literally and figuratively.

One of her first general conclusions about life and life limitations comes as an early recollection. Right after being adopted by the Neukirchens M.R. gets the feeling that "It was a good thing, to grow. Perceiving, even as a child, that you must grow or you will vanish." (Oates (b): 214). In a "grow" or "vanish" dialectic thinking to "grow" is the only acceptable thing. "Self-overcoming" also means, in Richard Rorty's system, "appropriating contingency" (Rorty, 1989: 27), accepting limitations as thresholds for the consolidation of the Self. As a fictional persona of Kelly Kelleher, Meredith Ruth plays the part of a redeemer, whose entire fictional existence is motivated by the will to reach a superior level of consciousness by attaining redemption as a validation of the self.

It is the difference between thinking of redemption and making contact with something larger and more enduring that oneself and redemption as Nietzsche describes it: "recreating all 'it was' into a 'thus I willed to'" (Rorty, 1979: 29). 
Admitting that "all it was" could hint at a fictionalized transpersonal memory giving access to Kelly's experience in Black Water, "thus I willed to" retraces the writer's intention to produce such "anastomotic" connection of the two narratives. These few considerations take us back to the means and meanings of fiction and its ability to bring together all three essential agents: the author, the reader/interpreter and the text itself.

The fiction-to-fiction transfer of disembodied consciousness is therefore entirely subjective and relies on its very own "contingencies".

\section{3. "Waiting Amid Tall Grasses"}

The very idea of redemption installs the fictional anastomotic bond into a guilt/punishment configuration which also activates the death/resurrection complex. Facing the past becomes a way to reinvent oneself, to get over traumatic events and therefore reach new levels of consciousness. Confronting the past is a necessary journey.

When she revisits the burnt-down house of the Skedds, her former foster family, deceased in a fire set by their mentally challenged daughter Lizabeth, Meredith Ruth is subjected to yet another stage of regression: standing before the ruins of her past, she is also connected to Kelly's own disembodiment experience. In her very last moment of life, little Alice-like girl sees her parents in grief, much older than she had ever seen them:

[...]seeing too Mommy and Daddy waiting amid the tall grasses though she was puzzled that now they were not young in fact but old, older than she knew, their faces haggard with grief staring in horror as if they had never seen her before in their lives, Kelly, little Lizabeth, as if they did not recognize her running there squealing in expectation in joy in her little white anklet socks raising her arms to be lifted high kicking in the air as the black water filled her lungs, and she died (Oates, 1994: 153-154).

The perspective gradually shifts to a bird's-eye view, as the embodied consciousness progressively rises from her body into the ethereal sky. More and more details accumulate: her aging parents await into the "tall grasses" a loved one that would never return, their eyes struck dumb in 
HSS, vol. V, no. 3 (2016): 77-92

the pain of the recent loss. The wild vegetation symbolizes both dismay and disorganization of life as it used to be. Time accelerates into a future-without-future leaving its marks on the human body restricted to the laws of the immanent. The ether thus becomes the environment of regression: time encapsulates as the ethereal consciousness approaches the eternal hereafter, completely detached from the body. The loose weeds are the world's way to measure earthly time which no longer applies to Kelly Kelleher.

In Mudwoman it is precisely time which is being measured in years of suffering and frustration. Still, before the ruins of what once was her home, Meredith Ruth obtains closure, liberation from the traumas of her past:

Remains of the asphalt-sided house that had seemed to her as a child so stocky-solid, like Floyd Skedd, were collapsed in ruins, scarcely recognizable. Boards and shingles burnt, rotted. And everywhere tall grasses, shrubs and trees, had grown over it. M. R. stood in the tall grass brushing away insects (Oates, 2012: 388).

Strolling amid the ruins of her past "cleansed" through a justified and purifying fire, M. R. feels at peace with the traumatic events having taken place in the old Skedd house. The woman is symbolically avenged by the gesture of a certain 'Lizabeth - who could be considered the phantasmatic return of Kelly, seeking justice. The natural rhythm of the universe is reinstalled, bringing peace and an odd sense of harmony. Meredith Ruth's own fictional existence is related to her understanding of alterity, for this woman has always felt, apparently, the shadow of a fictional past transgressing her own.

It was a classical paradox in philosophy: where is the self?

In the body or in - the soul?

Is there in fact a self?

Or rather - selves?

Or rather (this horror the more contemplated in the stark bright sunshine following an insomniac night) - no self except brain-matter on the perpetual verge of being extinguished (Oates, 2012: 272). 
HSS, vol. V, no. 3 (2016): 77-92

Such precarious state of the bodily unity thus dissolved by the accumulation of various discordant "selves" dismantles the external reality which becomes an outer expression of a troublesome and ever changing subjectiveness. Closure comes when the inner world reaches a state of complete serenity, and when the past ceases to be more present than the present itself.

\section{Removing the Threads. Insights}

Such a "transversal reading" leaves aside many other common elements connecting the two narratives. Both Black Water and Mudwoman appear to contain gothic elements, typical of Joyce Carol Oates's literary sensibility. The journey of a fictionalized "soul" into another fictionalized body is therefore less improbable, as it has to do with the writer's own literary obsessions and preferences. The "anastomotic" point of view concerns the three agents involved in the process: the character, as an embodied fictional presence, the author and her own personal history, and the reader.

As it is entirely subjective, this dialogue does not allow any general considerations. However, merging the two stories together could give an idea about the fact that the fictionalized consciousness "travels" from one narrative to another raising the question of fictionalized embodiment.

This fiction-to-fiction symbolic transfer does not exclude a third instance: the reader's very own consciousness, subjectively linking them together. From Mary-Jo Kopechne's real life and death story to the fictionalized Kelly Kelleher's, from echoes of Alice in Wonderland's fictionalized projection reverberating into the author's personal biography to Meredith Ruth's forged story as to remind Kelly's, the "anastomotic" logic subjectively connects both fiction and reality.

\section{References}

Oates, J. C. (1994). Black Water. A Novel. London: Picador in Association with MacMillan.

Oates, J. C. (2012). Mudwoman. London: Fourt Estate. An Imprint of Harper Collins Publishers. 
HSS, vol. V, no. 3 (2016): 77-92

Carroll, L. (1865). Alice's Adventures in Wonderland. With Forty-Two Illustrations by John Tenniel, Chicago: Volume One Publishing, 1998; A Book Virtual Digital Edition v. 1.2 November 2000.

Deleuze, G., Guattari, F. [1987] (2005). A Thousand Plateaus. Capitalism and Schizophrenia. Translation and Foreword by Brian Massumi, Minneapolis London: University of Minnesota. Eleventh Printing.

Lacan, J. (2006). "The Mirror Stage as Formative of the I Function as Revealed in Psychoanalytic Experience". Delivered on July 17, 1949, in Zurich at the Sixteenth International Congress of Psychoanalysis". Écrits. The First Complete Edition in English. Translated by Bruce Finck in Collaboration with Héloïse Finck and Russell Grigg, New York London: WW Norton \&Company.

Rorty, R. (1979). Philosophy and the Mirror of Nature, Princeton, New Jersey: Princeton University Press.

Rorty, R. (1989). Contingency, irony and solidarity, Cambridge: Cambridge University Press.

1 For further information see http://www.history.com/this-day-inhistory/incident-on-chappaquiddick-island.

Ted Kennedy's speech following the Chappaquiddick tragedy available at http://www.americanrhetoric.com/speeches/tedkennedychappaquiddick.htm

${ }^{2}$ In an interview with Katie Couric for NBC Channel in 1992, Joyce Carol Oates confesses that the idea to write a novel on the subject had haunted her for a very long time: "I felt this - this tremendous vacuum in a sense, a silence, about the victim and I wanted to get into the victim's consciousness. She had a story to tell, too, and I wanted to tell the story." (See the transcript of the interview at https://archives.nbclearn.com/portal/site/k-12/flatview?cuecard=64740 ).

${ }^{3}$ Joyce Carol Oates. (1994). Black W ater. A Novel. London: Picador in Association with MacMillan. 3.

${ }^{4}$ As Kelly Kelleher before, this trip challenges Meredith Ruth to face her past: at the age of three, the innocent child then named Jewel Kraeck was nearly drowned in the marshlands of Blake Snake River where she had been intentionally tossed by a mentally disabled mother. The very process of reaching superior levels of consciousness is thus represented by Meredith Ruth's alternative identities: born as Jewel, mistaken for her sister Jedina whom their mother had managed to kill, the little girl becomes Mudgirl, in her foster family; when adopted, her name is changed to Meredith Ruth (Merry) Neukirchen, then simply condensed to M. R. when 
HSS, vol. V, no. 3 (2016): 77-92

acceding to the University Presidency and finally M. on some other occasions. The more she climbs the professional hierarchy, the more she losses contact to her "selves". Coming back to her roots triggers a sort of rewind stretching from the complete abstraction (as "M.") to the first and utter "self" (as Jewel).

${ }^{5}$ As she often confesses it, Joyce Carol Oates relates profoundly to Lewis Carroll's masterpiece, since it connects her to childhood and her own Grandmother who gave her a copy of the story: "Alice is a character in a story and must embody, throughout, a modicum of good manners and common sense. Though a child like me, she wasn't telling her own story: That godly privilege resided with someone named, in gilt letters on the book's spine, 'Lewis Carroll'.' https:/ / celestialtimepiece.com/2015/02/14/stories-that-define-me/

${ }^{6}$ Jacques Lacan. (2006). "The Mirror Stage as Formative of the I Function as Revealed in Psychoanalytic Experience. Delivered on July 18, 1949, in Zurich at the Sixteenth International Congress of Psychoanalysis", Écrits. The First Complete Edition in English. Translated by Bruce Finck in Collaboration with Héloïse Finck and Russell Grigg, New York London: WW Norton \&Company. 75-81.

7 In R. Rorty's opinion, nature is experienced as "familiar and manageable" through language; spirit, however, "is so unfamiliar and unmanageable" that language may be insufficiently precise to render its inherent and continuous vacillation.

\section{Biographical note}

Andreea Pop has a $\mathrm{PhD}$ in comparative literature at the Babeş-Bolyai University Cluj-Napoca and Blaise Pascal University, Clermont-Ferrand II, France, on the subject of "The Vanishing Body in the Work of Several Francophone and Anglophone Writers: Marie-Claire Blais, Pascal Bruckner, Marcel Moreau. John Banville, Ian McEwan, Joyce Carol Oates". 